

\section{International Conference}

\section{on}

\section{Language, Literature and \\ Cultural Study (LLCS-2020) \\ Oct 29-30, 2020}

Copyright ( 2020 International Research and Development Center for Publication

DOI: $\underline{10.22161 / \text { conf.1lcs.oct.2020 }}$

ISBN: 978-81-948987-9-5

\section{Publisher}

\section{IRDCP}

Email: irdcp.publication@gmail.com |conference.irdcp@gmail.com

Web: https://irdcp.org/ 


\section{$\underline{\text { About IRDCP }}$}

International Research and Development Center for Publication (IRDCP) is a nonprofit organization for promoting research and development around the world. IRDCP is the bridge between the quality publisher and researchers. It provides the platform to researchers and academicians for publication in the Scopus Indexed Journals, SCI Journals, Web of Science Journals, UGC Approved Journals, NAAS Rated Journals, Google Scholar Indexed Journals and other good quality DOI journals.

IRDCP is also a partner organization for publication in conference proceedings. We organize the International conferences for publication in SCOPUS indexed and other refereed journals as per the requirement of the authors of the manuscripts. The manuscripts submitted to IRDCP should be plagiarism free and well coherent in all sense.

The scope of publication with the IRDCP covers all type of review and research manuscripts including the Exploratory \& Explanatory Research, Descriptive \& Theoretical Research, Applied Research \& Action Research, Cross-Sectional Research, Quantitative \& Qualitative Research in the field of engineering \& technology, agriculture \& environmental, Social science \& Humanities, Literature \& Education development, Medical \& Health Science.

\section{The vision of IRDCP :}

IRDCP endeavors to promote global excellence in the field of research \& development through diligent applications of advanced technology for the holistic development of society. Also, IRDCP is committed to motivate and persuade the researchers to take up the projects for the continuous development of human society and make this world a better place to live in. The IRDCP has a steadfast commitment be the fulcrum of the ocean of knowledge around which efforts of researchers move about. 


\section{$\underline{\text { About Conference }}$ \\ International Conference on Language, Literature and Cultural Study (LLCS-2020)}

During the worldwide lockdown due to COVID 19 pandemic, a lot of important activities have come to a halt. However, when we look at the brighter side, all of us have more time for adding to our knowledge and insights.

With this aim, to keep contributing to learning and motivation International research and development Center for publication is going to organize a two-day International Conference with the title "International Conference on Language, Literature and Cultural Study (LLCS-2020)" on Oct 29-30, 2020 through online mode.

We hope, this online mode of the conference in COVID-19 pandemic will be an appreciable step in promoting the research activities and new information between researchers, developers, students, academicians and practitioners working in and around the world by keeping the social distance in view to stop the spread of COVID-19 disease. This conference aims is to present the current researches being carried out in the field of social science and education development around the globe.

Prospective authors from academia as well as industry are invited to submit their abstracts that illustrate original/unpublished works and industrial applications describing advances and significant innovations in the field. 


\section{$\underline{\text { International Advisory Committee }}$}

- Prof. Liu Wenxiang, Hubei University, Wuhan, China

- Prof. Dr. Flávio de São Pedro Filho, Coordinator of the GEITEC / UNIR / CNPq, Brazil. Federal University of Rondônia, Brazil

- Prof Dr. Noman Omar Sattar, National Defense University, Islamabad, Pakistan

- Dr. Sunil Kumar Mishra, Amity School of Liberal Art, India

- Dr. Mahona Joseph Paschal, Service-Learning ambassador in Tanzania.

- Titus O. Pacho, Kisii university, Kenya

- Demetria Gerold Mkulu, St. Augustine University of Tanzania

- Dr. Neel Kamal Purohit, S.S. Jain Subodh P.G. College, Rambagh, Jaipur, India

- Dr. Parul Mishra, GD GOENKA University, India

- Dr. P. D. Nimsarkar, RTM Nagpur University Nagpur, India

- Dr. Sandhya Lanjewar, Central Institute of English Hyderabad, India

- Dr. Anil Matthew, Research Supervisor, Former Head of Department of English, Hislop College Nagpur, India

- Dr. Jyoti Patil, Principal, Renuka Mahavidyalaya, Besa Nagpur, India

- Dr. Md Mahadhi Hasan, Assistant Professor, Department of English, Southeast University, Bangladesh. 


\section{Message}

I am extremely pleased to share that International Research and Development Center for Publication (IRDCP) is organizing a two days International Conference on Language, Literature and Cultural Study (LLCS-2020) on Oct 29-30, 2020.

I am sure the state of art lectures from the invited experts and the research findings of researchers, academicians, utility engineers will enrich the knowledge of all the participants. It will provide an excellent opportunity for students to learn new ideas.

I offer my best wishes to the whole team of the organizing committee, the participants, and volunteers for the grand success of the conference.

Dr. Kiran

Convenor LLCS-2020 


\section{Message}

I am happy to know that International Research and Development Center for Publication (IRDCP) is organizing a two days International Conference on Language, Literature and Cultural Study (LLCS-2020) on Oct 29-30, 2020. I am sure that, this conference would provide an ideal platform for the academicians, scholars and experts to present and exchange their research findings and Ideas.

I wish the conference a great success.

Dr. Shyampada Mandal 
Thematic and Narrative Standards in American Cinema: An Analysis onCharacter Arc, Catharsis and Audience's Bias

David Sunil

Richardson's Pamela: Predicaments to Handle in Pamela's Marriage

Gassim H. Dohal

Toward an integral approach in the assessment and diagnosis of language disorders

José Alonso Aguilar-Valera, Gilmar William Guevara Ortega

Ernest Hemingway's a Farewell to Arms: A Tale of Love against the background of War

Dr Mayurkumar Mukundbhai Solanki

Reflections of Sufi Elements in the lore of Jalaluddin Rumi: A High Standard

Sonia Chadha, Dr. Parul Mishra 

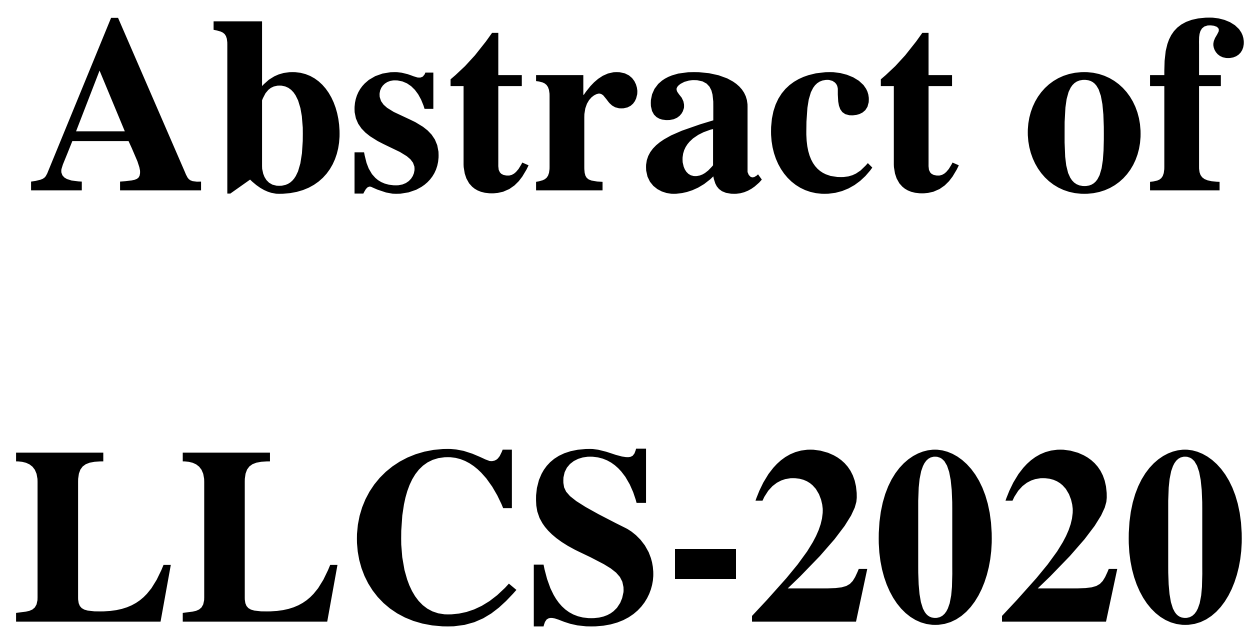


\title{
Thematic and Narrative Standards in American Cinema: An Analysis onCharacter Arc, Catharsis and Audience's Bias
}

\author{
David Sunil
}

Sivananda Sarma RV Memorial College, Karnataka, India

\begin{abstract}
Movies and TV series are a visual medium, that are intended to evoke the sensory root of vision and the audtitory system. The niche, in the cinematic and the television medium is not the mere presence of a story and the subsequent plot attached to it but it is the culmination of expert writing, character arcs (of all the characters) in the movie and TV series, the cathartic experience of the protagonist/antagonist and the plot that builds up to a boiling point which has nowhere to go other than to ingrain in the psyche of the audience. The cinematic and television masterpiece that demands further analysis by critics, which becomes the standard on which many other movies and TV series are made, is not without its own flaws. In spite of said existing flaws, there seems to be a glaring indication that the movie and TV masterpiece has the above qualities mentioned in order to fulfil its place as the 'movie of all movies' or simple put cinematic materpeices. For the sake of brevity and convenience, let us call the criteria in which every movie must be judged as writing, character arc, catharsis and plot or 'WCACP' analysis, for short. Critically acclaimed movies (Christopher Nolan's moveis) and television series (Breaking Bad) have an unparralled depth in them that other modern movies or TV series simply fail to match, baring a few exceptions like Francis Ford Coppola's The Godfather Trilogy (1972-1990), Brial De Palma's Scarface (1983), all of Martin Scorscese's movies, Stanley Kubrik's movies such as 2001: A Space Odyssey (1968), The Shining (1980) and Dr. Strangelove (1964), Orson Welles's Citizen Kane (1941) and the 'master of suspense' Alfred Hitchcock's movies such as Psycho (1960) and Vertigo (1958) to name a few. The aim of this paper is to formulate a link between the biases of the audience as well the struggle of the directors and the writers in producing a work of art, being cinema. The audience's reaction to a particular genre of movies and TV series as well as the category of audience that the writers and directors focus on is a key aspect to dwell deep into.
\end{abstract}


Keywords - Audience psyche, catharsis, character arc, cinematic medium, plot, writing.

\section{References:}

[1] Alibbi, Andrew. (2014). Hollywood, The American Image And The Global Film Industry. CINEJ Cinema Journal. 3. 10.5195/cinej.2013.81.

[2] Horak, J.-C. (2005). American cinema's transitional era. Audiences, institutions, practices (Charles Keil \& Shelley Stamp). Screening the Past, No. 18.

[3] Joseph, R. (2011). Disappearing in Plain Sight: The Magic Trick and the Missed Event. Octopus: A Journal of Visual Studies.

[4] Brislin, Tom (2016/10/01). Time, Ethics, and the Films of Christopher Nolan. Visual Communication Quarterly, 23, 199-209. doi: 10.1080/15551393.2016.1252655

[5] Kokeš, R. D. (2007). 2007 - "An Aesthetics of Astonishment" from Storytelling: Selfreflexive Tendencies of Narrative Strategies in Contemporary Hollywood Cinema (2005-2006). Douglasovy Poznámky: Poetika Fikce (Blog) [Douglas' Remarks: The Poetics of Fiction].

[6] Jensby, L. (2020). The Monster in the Labyrinth - Finding Your Way In and Out of Inception. Http://Fantastischeantike.de/the-Monster-in-the-Labyrinth-Finding-YourWay-in-and-out-of-Inception/.

[7] McGregor, R. (2014). Cinematic Philosophy. The Journal of Aesthetics and Art Criticism.

[8] García Martínez, Alberto \& Echart, Pablo. (2013). Crime and Punishment: Greed, Pride and Guilt in 'Breaking Bad'. 10.1163/9781848882706_018.

[9] Rasmussen, D. (2018). Intertextual Representations of Drugs, Violence, and Greed in Breaking Bad. Https://Harvest.usask.ca/Handle/10388/11916.

[10] Beck, K. (2021). Simone de Beauvoir meets Walter White: Breaking Bad as Authentic Literature. Television Series as Literature. 


\title{
Richardson's Pamela: Predicaments to Handle in Pamela's Marriage
}

\author{
Gassim H. Dohal, Ph. D.
}

English Teacher, Gizan, Saudi Arabia

\begin{abstract}
In this presentation, I will tackle some social elements that we can learn from Richardson's Pamela. Well, many things in this masterpiece are promising that Pamela and Mr. B's marriage will be successful; e.g. the change of Mr. B's behavior towards Pamela. Yet, we have to consider the social backgrounds of this couple, the marriage across class-line and age-line, as well as Mr. B's jealousy.

Indeed, both Pamela and Mr. B have many good virtues that will enable them to have a happy marriage life. At the same time, we shouldn't ignore those enigmatic barriers that they have to handle and be aware of. These obstacles will be of different natures; social, educational, psychological, etc. These barriers may take place in any marriage case; hence I will tackle these barriers as presented in the novel, hoping that this way will shed light on lessons readers may extract from Pamela.
\end{abstract}

Keywords - Richardson, Pamela; or, Virtue Rewarded, marriage, Mr. B, Pamela.

\section{References:}

[1] Albert, E. (1979).History of English Literature. London: George G. Harrup \& Co. Ltd.

[2] Armstrong, N. (1987).Desire and Domestic Fiction: A Political History of the Novel. New York: Oxford UP.

[3] Doody, M. A. (1974).A Natural Passion: A Study of the Novels of Samuel Richardson. Oxford: Clarendon Press.

[4] - - -. (1995). Introduction to Samuel Richardson's Pamela. Viking Press.

[5] McKeon, M. (2002).The Origins of the English Novel: 1600-1740. Baltimore: Johns Hopkins UP.

[6] Richardson, S. (1971).Pamela; or, Virtue Rewarded. Ed. T.C.D. Eaves and Ben D. Kimpel. Boston: Houghton Mifflin. 
[7] Thornley, G. C. and Gwyneth R. (1984).An Outline of English Literature. Longman Group Ltd.

[8] Watt, I. (1957).The Rise of the Novel: Studies in Defoe, Richardson and Fielding. Berkeley: University of California Press. 


\title{
Toward an integral approach in the assessment and diagnosis of language disorders
}

\author{
José Alonso Aguilar-Valera $^{1}$, Gilmar William Guevara Ortega ${ }^{2}$ \\ ${ }^{1}$ Kazan Federal University, Kazan, Republic of Tatarstan, Russian Federation \\ ${ }^{2}$ National University of San Marcos, Lima, Department of Lima, Peru
}

\begin{abstract}
The present work consists in a general exposition, from a comprehensive vision, of the three main levels, necessary to take into account when carrying out the study of language disorders - both innate and acquired- from a neuropsychinguistic approach. A tiered approach would facilitate the understanding of the different components that are part of the linguistic processing system (LPS). The development of a neuropsychinguistic model, which considers both neurobiology -at least from a referential point of view- and verbal behavior -through the studies carried out in experimental linguistics-, based on a main axis, formed by the different cognitive processes -both basic and complex- that constitute the support of cognitive activity and, mainly, of the LPS, would respond to an innovative proposal -although not necessarily new- that would allow covering a large part of the needs at the time of carrying out the evaluation, diagnosis and rehabilitation of the different linguistic alterations. Its antecedents and its applied importance will be reviewed, starting from a possible proposal, and of projection towards the future, emphasizing and delimiting the necessary criteria for its approach in the field of clinical practice.
\end{abstract}

Keywords - Neuropsychinguistics, language disorders, linguistic processing system, cognitive neuropsychology, evaluation, diagnosis, rehabilitation, pedagogical innovation.

\section{References:}

[1] Benedet, M. (2013). Cuando la "Dislexia" no es Dislexia. Un acercamiento desde la neurociencia cognitiva. Madrid: Ciencias de la Educación Preescolar y Especial.

[2] Caramazza, A., \& Colthear, M. (2006). Cognitive neuropsychology twenty years on. 
[3] Cognitive Neuropsychology, 23(1), 3-12.

[4] Chevrie-Muller, C., y Narbona, J. (2001). El lenguaje del niño. Desarrollo normal, evaluación y trastornos. Barcelona: Masson.

[5] Cuetos, F. (2012). Neurociencia del lenguaje. Bases neurológicas e implicaciones clínicas.

[6] Madrid: Médica Panamericana.

[7] Davies, M. (2010). Double Dissociation: Understanding its Role in Cognitive Neuropsychology. Mind \& Language, 25(5), 500-540.

[8] Fodor, J. (1983). The Modularity of Mind. Cambridge: MIT/Bradford Press.

[9] Krestel, H. (2013). Language and brain: historical introduction to models of language and aphasia. Swiss Archives of Neurology and Psychiatry, 164(8), 262-265.

[10] Peña, J., y Diéguez-Vide, F. (2012).Cerebro y lenguaje. Una sintomatología neurolingüística. Madrid: Médica Panamericana.

[11] Pereira, B. (2010). Methodological issues and controversies in research on cognitive disorders. Dementia \& Neuropsychologia, 4(4), 268-276.

[12] Prins, R., \& Bastiaanse, R. (2006). The early history of aphasiology: From the Egyptian surgeons (c. $1700 \mathrm{BC}$ ) to Broca (1861). Aphasiology, 20(8), 762-791.

[13] Richards, J., y Rodgers, T. (2001). Enfoques y métodos en la enseñanza de idiomas.

[14] Madrid: Cambridge University Press.

[15] Shayna, R., Gilboa, A., and Moscovitch, M. (2014). Case studies continue to illuminate the cognitive neuroscience of memory. Annals of the New York Academy of Sciences, $1316,105-133$. 


\title{
Ernest Hemingway's a Farewell to Arms: A Tale of Love against the background of War
}

\author{
Dr Mayurkumar Mukundbhai Solanki
}

\begin{abstract}
Assistant Professor of English, Growmore College of Engineering Himatnagar, Gujarat, India
\end{abstract}

\begin{abstract}
Hemingway's A Farewell to Arms has autobiographical elements that reveal the author's life story. Lt.Frederic Henry, the narrator, tells the story of his love affair with Catherine Barkley, a nurse in the hospital. Being an eye witness and served as a soldier during World War I, Hemingway seems to favour humanity, love and peace in the novel. He considers the war as futile and venomous for mankind. Hemingway himself passed through upheavals of life but there was a little hope to get love in life. Love brings liveliness to man's life. Plato considered love as the solution to all the problems. This paper is a sincere effort to evaluate Hemingway's $A$ Farewell to Arms as a tale of love against the background of the war.
\end{abstract}

Keywords — Love affair, peace, World War I, humanity ,futile, solution.

\section{References :}

[1] https://libcom.org/files/farewelltoarms01hemi.pdf

[2] Ibid.9

[3] Ibid.27

[4] Ibid.31

[5] Ibid.38

[6] Shams, Ishteyaque, The Novels of Ernest Hemingway : A Critical Study. Atlantic Publisher and Distributors, New Delhi. 2002. p.42.

[7] Ibid. 43

[8] Ibid.44

[9] Ibid.46

[10] Ibid. 50 
International Conference on Language, Literature and Cultural Study (LLCS-2020) Oct 29-30, 2020

https://irdcp.org/conferences

[11] Ibid. 56

[12] Ibid. 57

[13] Ibid.58 


\title{
Reflections of Sufi Elements in the lore of Jalaluddin Rumi: A High Standard
}

\author{
Sonia Chadha*, Dr. Parul Mishra \\ G.D. Goenka University, Gurugram, Delhi, India \\ *Corresponding author
}

\begin{abstract}
Rumi might be first Preacher of Sufism to foster a spirit of unity among all human being and people all over world designated the moral message. Through his piece of literature he delivered a message of aspiration, devotion, adoration, brotherhood, amity, understanding, charity, peace and tranquility in entire universe. He had broken the linguistic boundary and created a high standard of poetry. Sufi is a path of purity and by following it a person gets pure from the lore of his heart. Rumi being the follower of Sufi emerged in the period when religious chaos was on its crescendo and he being illiterate presented his dogmas weave in words to maintain serene and peace.
\end{abstract}

The purport of this paper is to root out Rumi's Poetry edifice with a higher pennon. This could happened not because of compassion and tolerance but he put an exemplary atmosphere where these high values were upheld, he created a decent way through opening the door to dialogue through his simple message. He indeed was one of the perfect representatives of such a complete human one and considered one of the greatest teacher or deacon of universal love and peace. In Middle East and Western Asia Rumi was always a matter of attraction that was a major figure which had left an everlasting impact on wide variety of people because of simplicity and appealing words of choice. Even after eight century since his death his presence still astounds the western world. Sama or Fana so forth are well associated with his name and canonized him for his huge success. But in true sense he himself illuminated whole universe like Northern Star whose presence in sky means a matter of proud. This is in case of Rumi excessively. Sama or any act related to his name is a step ahead from his time. Such themes fabricated by him for whole humanity in a dignified way, undoubtedly Rumi upraised and designed a high standard of literature which is still peerless and inequitable. 
Keywords - High standard, Inequitable, Sama, Sufi elements, Whole humanity.

\section{References:}

[1] Arberry, A.J. Mystical poems of Rumi. University of Chicago Press, 1968, pp.20-208

[2] Barks, Coleman. The glance songs of soul-meeting. Penguin publishing group, October 1999, pp.35-112

[3] Carmody Lardner Denise and Carmody Tully John. Mysticism Holiness East and West. Oxford University Press, 1996, pp. 100-336

[4] Helminski, Edmud Kabir. The Rumi Collection. Shambhala Publications, June 2005, pp.150304.

[5] Khalili, Nader. The spiritual poems of Rumi. Wellfleet, September 15 2020, pp.13-128

[6] Ladinsky, Daniel. The purity of desire 100 poems of Rumi. Penguin Publishing, November 2012, pp.15-118

[7] Mojaddedi, Jawid. Beyond Dogma Rumi's teachings on Friendship with and Early Sufi Theories. Oxford University Press, 2012

[8] Whinfield, E.H. Translator. Teaching of Rumi. The Masnavi. Octagon Press, January 1979, pp.25-330. 